\title{
English Language Teacher Professional Development During COVID-19 in Nepal
}

\author{
Ganga Ram Gautam, PhD \\ ganga.gautam@tu.edu.np \\ Director \\ Open and Distance Education Center (ODEC) \\ Tribhuvan University
}

\begin{abstract}
COVID-19 pandemic has brought a big pedagogical shift in education across the board. In this context, teachers expected to be adaptable in the new situation in by familiarizing themselves to the emerging technology-driven pedagogy. This article explores how 102 English language teachers in Nepal prepared themselves to respond to COVID19 by attending various professional development events organized between April and September 2020 by different professional forums and organizations. The results show that English teachers in Nepal attended three kinds of events that include training programs to learn technology, events to learn about the online resources for English language teaching and professional development events to enhance their professional skills. Participation in these events made English teachers digitally confident to run the classes online and increased awareness of the integration of online resources in English language teaching.
\end{abstract}

Key Words: ICT integration, professional development, online pedagogy

\section{The COVID-19 Pandemic and Education: 'emergency online homeschooling'} The first case of COVID-19 was spotted in Nepal on January 13, 2020 and the government initiated efforts to address this through various means. Since then the number of cases has increased and as of now (November 2020), more than 2,00,000 positive cases have been reported and about 1,300 deaths have been recorded. The country went into a complete lock down since March 24, 2020 and it was extended multiple times as the cases kept increasing. The lock down has been to some extent eased on June $14^{\text {th }}$ and offices are allowed to open in two shifts. Only half of the private vehicles were allowed to run in the roads and shopping malls, educational institutions, theaters, restaurants, airports (both domestic and international) were closed for a long time. The academic institutions were also closed and all the face-to-face classes were disrupted. This kind of unprecedented situation brought the country on a very difficult situation and almost all the sectors have suffered a lot due to the spread of COVID-19 pandemic all over Nepal. 
Education sector has suffered a lot by this pandemic. Classes have been disrupted, exams were on hold and teaching learning process became stand still due to the influx of the unprecedented virus. There was a lot of confusion in the beginning and we hoped that the crisis would go shortly after a few weeks. Unfortunately, the situation started becoming worse day by day and getting out of the pandemic became a distant dream. As the situation of pandemic became more unpredictable, government and universities initiated discussions to make efforts to respond to COVID-19 so that educational programs could be conducted through 'emergency online homeschooling' (Guzdial, 2020) or any other alternative means such as radio, television and so on. Consequently, government of Nepal issued a guidelines entitled "Facilitating Student Learning System through Alternative System - 2077" (in Nepali language) which paved the ways for schools to run classes using alternative tools such as radio, television, internet, email and so on. The curriculum, textbooks, teachers guides and other learning resources are uploaded on the webpage of the Curriculum Development Center (https://moecdc.gov.np/) and teachers could access them online to prepare their lessons for the learning facilitation. Efforts are now being made to teach school children through national and local TV channels, local FM radio, online tools and so on.

\section{Teachers During COVID-19: Search for Online Learning Opportunities}

The consequences of COVID-19 pandemic brought a new wave in teaching and learning. Teachers had to make a big leap in their pedagogy and they were required to make a shift from face-to-face teaching to virtual and online teaching. Tracing and contacting students, establishing connection through the electronic modes, setting up classes in the virtual world, engaging students on tasks and activities, facilitating learning through virtual modes were some of the immediate steps all teachers had to learn within no time (Allen, Rowan \& Singh, 2020). There was an unsurmountable pressure on teachers to make a shift to the alternative mode of teaching as quickly as possible but there was no organized support system in place for teachers to learn the new ways of doing. This situation brought confusion among teachers putting them in a very stressful situation. However, they used different coping strategies in order to stay aware of the situation and find ways of helping their students (Mac Intyre, Gregersen \& Mercer, 2020). As the pandemic surge continued rising and school closure prolonged, they began to search for opportunities to learn not only how to teach online but also the tools and resources for virtual pedagogy. This study was an attempt to explore how English teachers in Nepal engaged in various professional development opportunities and what they were able to learn from those events to enhance their professional competence during the COVID-19 pandemic.

Teacher professional development is an ongoing process. Professional development in normal situation is sometimes institutionalized where a designated unit is responsible to organize professional development events and in some other cases, it is more self-initiated by the teachers themselves. In case of the COVID-19 pandemic, there was no institutional arrangement for teacher professional development and teachers were on their own to find out the opportunities to learn to teach alternatively. Additionally, teachers were asking their friends, mentors, seniors and experts the ways to respond to COVID-19. So, in this context, professional development was more collaborative (Darling- Hammond and Hyler 2020) and self-regulated (Peel, 2020). They identified opportunities available around and attended the events of their choice in a more 
English Language Teacher Professional Development During COVID-19 in Nepall 105

self-directed learning mode (Mentz, de Beer \& Bailey, 2019). In order to develop themselves, teachers naturally look for the models and best practices in ELT (Coombe \& Khan, 2015; Kuchah\& Shamim, 2018; Simpson, 2013, for example) and learn from them.

\section{Situating the Study and Key Research Questions}

The country was going through the crisis caused by COVID-19 and teachers were trying to find ways of learning to teach online. For the last few years, I have been working in the Open and Distance Education Centre (ODEC) of Tribhuvan University (TU) and we are running two master's programs on a blended mode. Most of our teaching learning at ODEC takes place virtually and we have been using different tools and resources in our online teaching and learning. Due to my involvement in managing open and distance learning in TU, different professional forums and teacher network contacted me to facilitate online teacher training sessions for English language teachers during the pandemic. Leading teacher association of English teachers in the country called Nepal English Language Teachers' Association (NELTA) conducted a series of teacher training events across the country. I was invited in many of them to share online/ digital resources on English language teaching (ELT). During these sessions, I noticed that there was a great deal of enthusiasm among the English language teachers to learn how to teach online and they were very keen to explore the online resources which they could use to enhance their professional competence and improve their teaching. Despite the challenged faced by the on-going crisis caused by the pandemic, teachers were proactively looking for professional development opportunities. The zeal and active participation of teachers in the sessions that I facilitated, motivated me to me to carry out this research with the following two research questions:

a. What professional development opportunities were available for English teachers during the COVID-19 pandemic in Nepal?

b. What were the key professional learning areas that English teachers found useful to enhance their professional competence from the professional development activities that they attended during the pandemic?

In this study, I collected data from two different sources. In order to find out the nature of professional development activities, type of online/digital resources that they learned during those events and the contributions such events made to their teaching and learning of English, I developeda questionnaire and emailed it to 120 English teachers across the country in the month of September 2020. Out of them, only 102 of them returned the completed questionnaire. The participants included English teachers of all levels of education (16\% primary level, 54\% secondary level and 30\% college and university level) within the age range between $19-57$ years with 1 to 30 plus years of teaching experience. Regarding their familiarity with the technology, they rated themselves as beginners (35\%), moderate (47\%) and advance (18\%). The collected information was collated and thematically organized with reference to the key research questions. 


\section{Results and Discussion}

The data collected from the teachers indicate that teachers were actively engaged in various professional development opportunities during the pandemic and the findings show that such engagement has resulted enhanced professional competence among the English language teachers. The sections below present the results of the study along with the discussion of their contributions to teacher professional development.

\section{Professional Development Opportunities}

Since the COVID-19 pandemic began in Nepal, we havewitnessed a flood of webinars and online training events organized by different groups for teachers. Participants reported that they were overwhelmed by the events and it was sometimes very difficult to choose the right kind of event from the multiple happenings. There was so much going on around them and they wanted to participate in as many of them as possible. At the same time, they also had to take their classes and meet social and family obligations.

Basically, there were three different types of events that the participants attended viz. a) technology related events in order to learn how technology could be used for online teaching, b) English language teaching related events to use online resources in English language classes, and c) professional development events to enhance their professional understanding in the ELT and educational research areas.

\section{Technology related events}

One of the major challenges that the English teachers faced during the pandemic was the lack of adequate technological skills to deliver the courses online. Ninety two percent of the teachers under the study had no prior online teaching and learning experience. Only three percent had attended online courses sponsored by the Regional English Language Office (RELO) of the US Embassy and remaining five percent had attended courses on the MOOCS and the Coursera. Due to the lack of technical skills and lack of familiarity with the technological tools, there was a great deal of anxiety among most of the teachers (95\%) to switch to online mode of education. Thus, they were in search of the training opportunities to develop their digital literacy to handle the technological tools for online classes. Here's the summary of what they found and participated.

Table 1. Digital literacy training events teacher attended

\begin{tabular}{|c|l|c|}
\hline SN & \multicolumn{1}{|c|}{ Name of the training Events } & Number of Teachers \\
\hline 1 & Using Google classrooms & 75 \\
\hline 2 & Zoom technology for online teaching & 100 \\
\hline 3 & Microsoft Teams for online class & 38 \\
\hline 4 & Using Facebook messenger for online class & 42 \\
\hline 5 & Skype for business & 11 \\
\hline
\end{tabular}

Zoom technology was the main digital tool learned and used by most of the teachers for online classes followed by the Google class. The participants reported that zoom was user-friendly for the live classes but the 40 minutes duration per session in the free version was a major limitation to carry out extended activities during the online classes. Also, the frequent interruptions on the 
English Language Teacher Professional Development During COVID-19 in Nepall 107

internet was a big hurdle to get reconnected due to the limited knowledge and skills in handling the online features of the zoom technology. Participants also reported that Google class and Microsoft Teams contained some pedagogical features that include managing classes using the online calendar and a space to store reading materials. However, teachers shared that they had to learn and relearn how these tools could be handled for effective class delivery. Here's the observation of one of the participants,

I had no idea of what the Zoom was. When the facilitator told us how to use it, I thought I learned it but when I had to use it, I was not able to use it properly. I asked my brother at home and he helped me. Technology is not something that we can learn by attending a training session alone, we have to use it in order to master it.

In addition to these tools, participants also reported that they attended sessions on technology adaptations in the low or no resource context. Using a mobile phone and its applications for English language teaching including the dictionary use and listening practice were cited as the examples by some participants during the focused group discussion.

\section{English language teaching related events}

Participants said that online classes had the limitation of engaging students in language practice activities and many of them (66\%) were not aware of the available online resources for English language teaching. Only a few of them (34\%) were found to have learned about the online teaching resources that include www.teachingenglish.org.uk maintained by the British Council and www.americanenglish.state.gov maintained by the US State Department. Some of them (7\%) also attended the American English (AE) E-teacher Programs on various aspects of ELT.

Participants attended online events on different topics of ELT that include;

c. Activities for teaching vocabulary and grammar

d. Online resources for teaching different language skills

e. Board games and their use in English class

A teacher from Nawalparasi said,

I was using www.teachingenglish.org.uk site for my teaching and I used to design some classroom activities taking ideas from this site. During the lock down, I have downloaded about 450 pages of teaching resources from this site which I will use in my teaching in the future. My exploration to this site helped me get relieved from the COVID-19 stress.

\section{Online and Digital Resources for English Language Teaching}

One of the major accomplishments that English teachers reported during the pandemic is their familiarity with the online tools and resources on ELT. Teachers said that these resources are not only useful in teaching English but also contributory to enhance their (teachers') own English language proficiency. Some of the online resources that teachers learned from the events organized during the pandemic are briefly presented below. 
National Geographic Learning: https://ngllife.com/student-zone/interactive-reading-practice This page offers reading practice for different levels through the texts accompanied by interactive reading comprehension activities. There are ready-made lessons for teachers that include reading text in PDF format, reading comprehension activities in PDF version, supplementary vocabulary and grammar activities, audio file of the text and answer keys. Teachers said that the audio files are very helpful to combine listening and reading together to train students in micro reading skills. Altogether 47 percent of the teachers said that they are using this site to learn to teach reading to their students. Some of them (34\%) said that they use this site in order to practice their reading skills for themselves.

A teacher from Lalitpur mentions;

The reading texts in the textbook were not enough for reading practice. So, I choose the similar text from this site and engaged my students in reading practice. The resources on this site are very good and easy to handle. All the materials are ready-to-use and I made some adaptations particularly in the comprehension questions.

This shows that teachers not only used these resources as lessons but also learned how similar activities could be developed from the textbooks they were using.

\section{Elllo: http://www.elllo.org}

This is another site which teachers found useful for listening comprehension. The site offers a wealth of listening exercises in video or audio format. You can sort search results by level, topic, country or media. The site contains listening text, exercises with vocabulary lists, additional exercises or quizzes, download links and audio with English speakers of different nationalities. Among the teachers under this study, about $77 \%$ teachers said that they have used this site to practice their listening comprehension during the lock down. Many of them also shared during the focused group discussion that this site was helpful to make preparation for the IELTS and TOEFL tests they would like to attend in the future. A few of them (19\%) said that they shared this site with their children and their children who then practiced their listening comprehension on this site.

I have two kids; one 10 years and 13 years old. I had a tough time to keep them busy. Since I learned about this site from the webinar that I attended, I told them about this site and since then they have been using this site to practice their English.

This indicates that online exposure during COVID-19 was extended beyond teaching and teachers have shared these sites not only with their students but also with their children.

\section{Learning English through Voice of America - https://learningenglish.voanews.com/}

Nearly a quarter of the participants said that they have used this particular site for the last many years and their students have found this useful to learn spoken English. The site contains video files followed by language learning activities. A teacher from Kathmandu shared; 
English Language Teacher Professional Development During COVID-19 in Nepall 109

My uncle used to talk about voice of America long time ago but I didn't think that this could be used for teaching and learning of English. My god! there is so much on this site and there are a number of lessons for us to use. All we need to do is to find the good one that suit in our context and use them. I am so happy!

Teachers during the discussion said that the video lessons on this site also expose the students to the American culture and students can discuss the similarities and differences between the cultural practices during and after the class.

Activities for ESL Students : http://a4esl.org/

Another rich site with abundant ESL resources that teachers have found useful is the a $4 \mathrm{esl}$ which include 1,000 activities on different aspects of ELT. Resources on this site are contributed by the teaches from around the world. About 40 percent participants were found to have visited this site frequently during the study period and classroom activities stored on this portal were used for various purposes.

Grammar practice activities are very good on this site. Grammar teaching was boring for me and now I make my grammar class interesting from the resources on this site.

American English Website : https://americanenglish.state.gov/

One of the sites which was mostly visited by the teachers $(77 \%)$ during the pandemic was the American English website that hosts the resources for teaching and learning of American English including the recorded webinars on professional development for English teachers. Teachers could also contribute to this site by uploading their experiences and best practices in teaching English and learn from their colleagues from around the world. One of the teachers from Kailalimentioned,

As an online training participant, I found the online resources shared by the facilitator very useful for those want to improve his/her English. For example, I would have never checked the webpage https://americanenglish.state.gov/ if I had not enrolled this online course. What I really liked about this site is that it provides materials for making teaching English a fun activity. I used listening exercise with my students of grade 8 when I was teaching online and students found it very useful.

Similarly, another teacher from Baglung stated;

What I really like about the American English site is the store of very useful resources that we can download. I found a book called, The Lighter Side of TEFL and I have printed it for my future use. I use the vocabulary activities from this book and students find them very interesting. There are so many books and other resources that we can download for free and use them for teaching English.

Awareness about the availability of the downloadable free online resources is another benefit that teachers realized by attending the online events during the COVID-19 pandemic. 


\section{Professional development events}

About half of the teachers (69\%) also attended various professional development events during the pandemic. Research seminars, ELT conferences organized by the teacher associations at home and abroad, teacher development workshop organized by teacher unions, online courses offered by various universities in the US, UK, Australia, and the online courses on MOOCS and Coursera were the major online programs that the participants attended during the pandemic. The Virtual Think-in 2020 programs organized by NELTA was one of the highlights for most of the teachers $(61 \%)$. They were unanimous in saying that this event brought the ELT practitioners from around the world on their computer at home and they were able to remotely interact with the world renowned ELT veterans. Among those who attended the program, 80 percent teachers said that this was the first experience for them attending the virtual professional development event in their life. So, they found it a rare event to have a global professional connection from their home.

The topics that teachers found most relevant in this particular event were related to the teaching of English during the COVID-19 and post COVID context. These sessions made them realize that the issues and challenges that teachers were facing in Nepal were common in many countries in the world and solutions to the challenges need to be sought based on the local contexts. One of the participant teacher from Dolakha district said,

I realized that it is not only me but all English teachers around the world like Japan, Malaysia, Thailand, Pakistan and many other countries are having similar issues in running the online classes. I learned different ways of teaching English online and I will now see how I can implement the ideas that I learned in this training in my school.

Some other topics the participants found relevant and interesting were

f. Challenges and solutions in online English teaching in China

g. Opportunities and strategies in education in post-COVID context

h. English pedagogy in hard times

i. Innovative approaches of teaching during pandemic

j. When life gives you lemons, make lemonade !

Similarly, teachers also attended research seminars organized by teacher groups and educational network. Clarity on the research methodology, dimensions of qualitative research in ELT, action research for professional development were some of the topics teachers found most useful that they attended during the study period. Also, the kind of mandatory transition to the online mode of situation created a sense of 'forced readiness' (Cutri, Mena \& Whiting, 2020)) which ultimately contributed to change the mindset of teachers for further learning and professional development.

\section{Issues and Challenges Faced by Teachers}

Despite the pleasure of learning various innovative ways of teaching online and familiarity with the wealth of online resources, teachers also faced a lot challenges to attend the professional 
English Language Teacher Professional Development During COVID-19 in Nepal/ 111

development events during the COVID-19. Time management was a big issue for many of them $(80 \%)$ as the events were organized by the organizations of the different time zones. Also, female teachers reported that most of the in-country events took place in the morning and evening which conflicted with the peak time for domestic chores that include cooking and other family events. Sickness in the family and relatives was another issue that distracted teachers from the professional events. Some other challenges cited by the teachers were the lack of technological competence to run some online applications, connectivity issue, non-scheduled power-cut, conflicting schedule with the online classes and compatibility of their equipment for the latest technology. However, teachers made their effort to patriciate in the events as much as possible and learn from them.

\section{Conclusion}

The entire country has been suffering from the COVID-19 pandemic but professionals working in different field including education have been trying their best to contribute to the national emergency through their good work. The shifting image of pedagogy during the COVID-19 pandemic increased the appetite for exploring the alternative modes of teaching and learning. Teachers invested their time and resources to learn new ways of teaching and they participated in various online learning opportunities to grow as a professional teacher. The study has indicated that teachers were very active during the pandemic to find ways of helping their students to the best possible way they could. Many of them had heard about the technology integration in education but the pandemic context gave them the real opportunity to experience ICT integration in the teaching and learning of English. The professional development journey during the pandemic served dual purpose for them. It was mandatory for them to be digitally literate and competent in using the online education tools. At the same time, they also had to learn how English language contents could be delivered online so that they can support their students to develop linguistic and communicative skills in the English language. The study shows that if there are opportunities around, teachers are self-motivated to learn and they can learn.

\section{References}

Allen, J., Rowan, L., \& Singh, P. (2020). Teaching and teacher education in the time of COVID19, Asia-Pacific Journal of Teacher Education, 48(3), 233-236. https://doi.org/10.1080 /1359866X.2020.1752051

Coombe, C. \& Khan, R. (2017). Best practices in ELT: Voices from the classroom. Dubai: TESOL Arabia.

Cutri, R.M, Mena, J., \& Whiting, E.F. (2020). Faculty readiness for online crisis teaching: transitioning to online teaching during the COVID-19 pandemic. European Journal of Teacher Education, 43(4), 523-541. https://doi.org/10.1080/02619768.2020.1815702.

Darling-Hammond, L., \&Hyler M. (2020). Preparing educators for the time of COVID . . . and beyond." European Journal of Teacher Education 43 (4): 457-465. doi:10.1080/02619 768.2020.1816961. 
Guzdial, M. (2020, March 30). So much to learn about emergency remote teaching, but so little to claim about online learning [blog post]: https://computinged.wordpress. com/2020/03/30/so-much-to-learn-about-emergency-remote-teaching-but-so-little-toclaim-about-online-learning/ retrieved on November 16, 2020.

Kuchah, K. \& Shamim, F. (2018). International perspectives on teaching English in difficult circumstances: Contexts, challenges and possibilities. London: Palgrave Micllan.

MacIntyre, P. D., Gregersen, T., \& Mercer, S. (2020). Language teachers' coping strategies during the Covid-19 conversion to online teaching: Correlations with stress, wellbeing and negative emotions. System, 94, 102352. https://doi.org/10.1016/j.system.2020.102352.

Mentz, E., de Beer, J. \& Bailey, R. (2019). Self-directed learning for the 21st century. AOSIS. Pretoria.

Ministry of Education Science and Technology (2020). Facilitating student learning system through alternative system - 2077" (in Nepali language). MOEST. Kathmandu.

Peel, K. L. 2020. "Everyday classroom teaching practices for self-Regulated Learning." Issues in Educational Research 30 (1): 260-282.

Simpson, J. (2013). The Routledge handbook of applied linguistics. New York: Routledge. 